\title{
Surgical Pearl: Dissecting Forceps with Polytube for Periorbital Senile Comedone Extraction
}

\author{
Muhammed Mukhtar (iD) ${ }^{1, *}$ \\ ${ }^{1}$ Mukhtar Skin Centre, Katihar Medical College Road, Katihar-854105, India \\ "Corresponding author: Mukhtar Skin Centre, Katihar Medical College Road, Katihar-854105, India. Email: drmmukhtar20@gmail.com
}

Received 2020 May 06; Revised 2020 June 08; Accepted 2020 June 08.

Keywords: Senile Comedone, Comedone extraction, Squeezing, Dissecting Forceps, Polytube, Eyelid, Periorbital Region

\section{Dear editor,}

Senile comedones are common on the actinically exposed facial skin of middle and old aged people. In $5.6 \%$ of the aged people, senile comedones are found in the periorbital region. (1). These senile comedones are composed of keratinous material, which is histologically surrounded by photodamaged elastotic tissues. It can be treated with topical retinaldehyde (2); however, these comedones are resistant to topical. Hence Dermatologists treat them with comedone extractors, light cautery, safety pins, pen punching, CO2 laser (3), versatile paper clips, disposable syringes (4), and tissue dissecting forceps (5), but these are not safe for loose tissue of eyelids and periorbital area. Direct squeezing out of the comedone can be done with fingers and forceps. However, the finger is not a good and aseptic method, and metallic forceps are not secured from getting tissue injury in the form of abrasion, subcutaneous bleeding, and senile purpura over the site.

Therefore, here I advised the use of a less injurious dissecting forceps to extract out senile comedones over the periorbital region and eyelids. Dissecting forceps are the readily available instrument in the clinic, which can be applied over the periorbital region. However, it is metallic, hard, and traumatic, which is made less traumatic by doing some modification in the tips of the forceps. To do this, first, two small pieces of tube of about 1-inch long are cut from aseptic refill polytube of ball pen, and then the tips of the forceps are embedded into the tube (Figure 1).

Following this, the periorbital comedone on the eyelid is made aseptic with lotion povidone-iodine and medical spirit (Figure 2A). The insulated tips of the forceps are also made aseptic before extracting the comedones (Figure 2B). The senile comedones are usually opened comedone. In the case of closed comedones, a minor prick incision was put with a disposable needle before the procedure. Then, the comedone is compressed out gently and safely with the

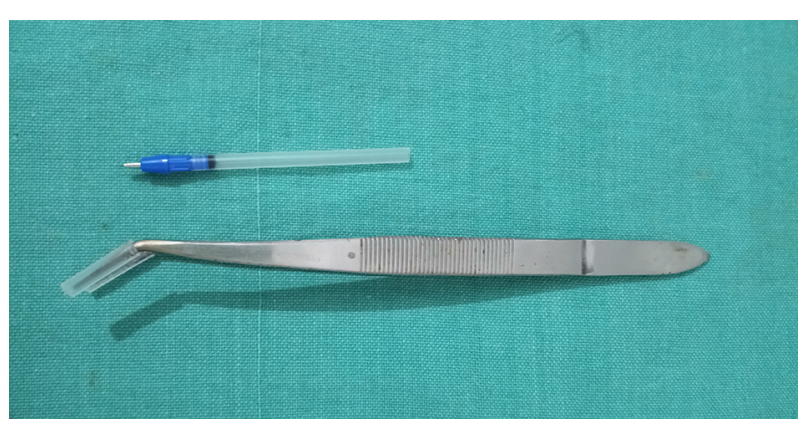

Figure 1. The forceps tips insulated with refill polytube of ball pen.

forceps applied twice at $90^{\circ}$ to one of the other (Figure $2 \mathrm{C}$ F). We observed the complete extraction of the keratinous material. This procedure could be repeated many times over comedones of the periorbital region. Post comedone extraction, no significant tissue injury and subcutaneous bleeding are observed over the sites. Thus, the dissecting forceps, with refill polytube insulated tips, makes the comedone extraction less injurious to the loose tissue of the eyelids.

In conclusion, senile comedones nonresponsive to medical treatment over eyelids and periorbital region can be extracted out atraumatically with polytube embedded tips of the tissue forceps, which could be a better option for the comedone extraction on loose tissue of other parts of the body.

\section{Footnotes}

Authors' Contribution: Being the only author, all contributions are made by the author.

Conflict of Interests: The authors declared no conflict of interest. 

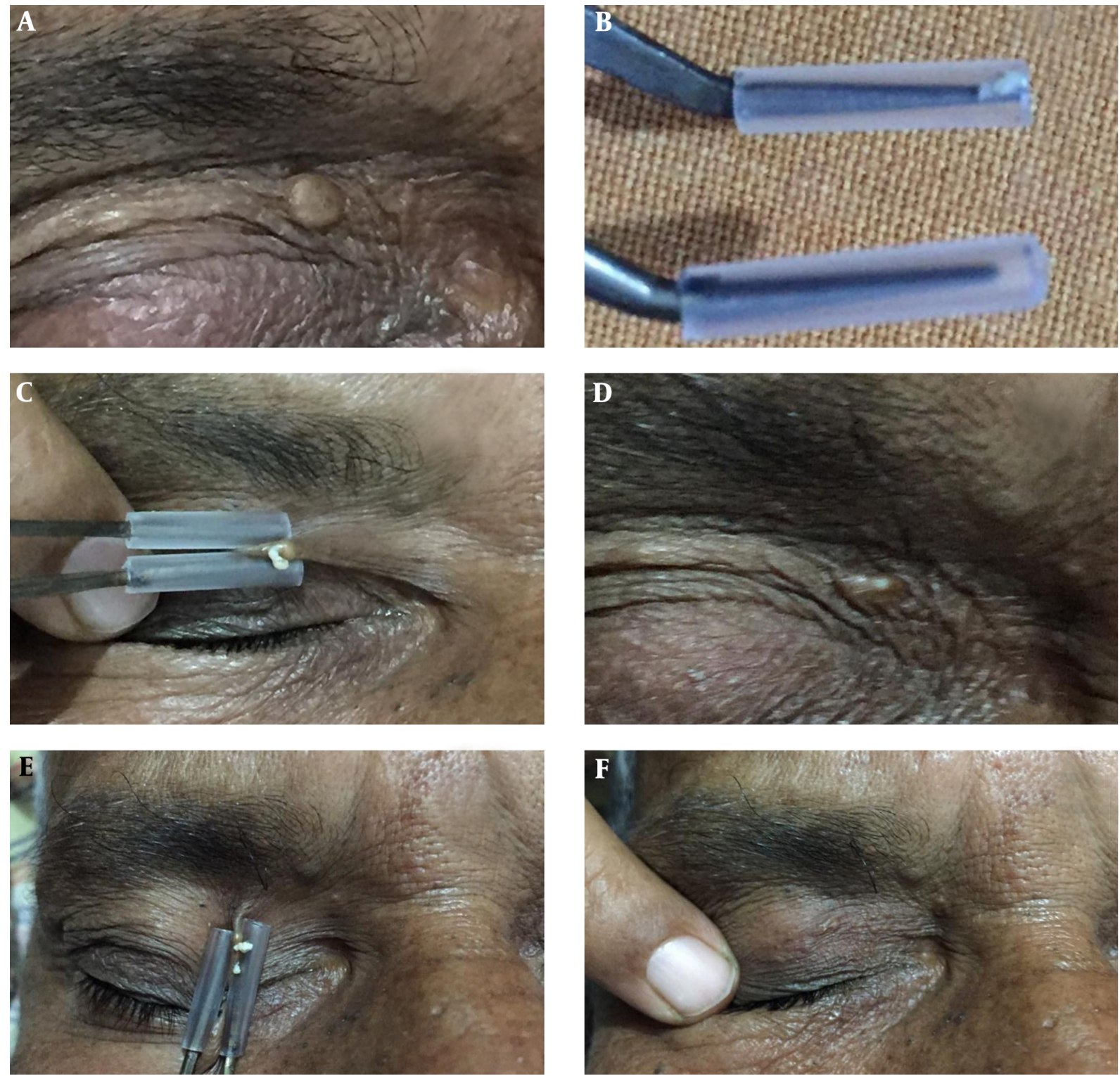

Figure 2. A) The senile comedone before its extraction. B) The forceps tips with aseptic refill polytube. C) The senile comedone is squeezed in the first attempt. D) The senile comedone with its remnant content after the first attempt. E) The senile comedones are squeezed at 90 degrees in the second attempt. F) The senile comedone is extracted out completely in the second attempt.

Ethical Approval: Not required.

Funding/Support: There was no funding/support.

\section{References}

1. Izumi AK, Marples RR, Kligman AM. Senile (solar) comedones. J Invest Dermatol. 1973;61(1):46-50. doi: 10.1111/1523-1747.ep12674145. [PubMed: 4268867].

2. Creidi P, Humbert P. Clinical use of topical retinaldehyde on photoaged skin. Dermatology. 1999;199 Suppl 1:49-52. doi: 10.1159/000051379. [PubMed: 10473961].
3. Rai S, Madan V, August PJ, Ferguson JE. Favre-Racouchot syndrome: a novel two-step treatment approach using the carbon dioxide laser. BrJ Dermatol. 2014;170(3):657-60. doi: 10.111//bjd.12742. [PubMed: 24252129].

4. Mukhtar M. Surgical pearl: disposable syringe as comedone extractor. Cosmetic Dermatol. 2003;16(5):57-8. doi: 10.1111/j.13654632.2004.02293.x.

5. Kaya TI, Tursen U, Kokturk A, Ikizoglu G. An effective extraction technique for the treatment of closed macrocomedones. Dermatol Surg. 2003;29(7):741-4. doi: 10.1046/j.1524-4725.2003.29190.x. [PubMed: 12828698]. 